\title{
Inactivation of an aminoaldehyde dehydrogenase is responsible for fragrance in rice
}

\author{
Louis M. T. Bradbury · Susan A. Gillies • \\ Donald J. Brushett · Daniel L. E. Waters • \\ Robert J. Henry
}

Received: 30 November 2007 / Accepted: 23 July 2008/Published online: 13 August 2008

(C) The Author(s) 2008. This article is published with open access at Springerlink.com

\begin{abstract}
Rice (Oryza sativa) has two betaine aldehyde dehydrogenase homologs, BAD1 and BAD2, encoded on chromosome four and chromosome eight respectively. BAD2 is responsible for the characteristic aroma of fragrant rice. Complementary DNA clones of both BAD1 and BAD2 were isolated and expressed in E. coli. BAD2 had optimum activity at $\mathrm{pH} 10$, little to no affinity towards $\mathrm{N}$ acetyl- $\gamma$-aminobutyraldehyde (NAGABald) with a $\mathrm{Km}$ of approximately $10 \mathrm{mM}$ and moderate affinity towards $\gamma$-guanidinobutyraldehyde (GGBald) and betaine aldehyde (bet-ald) with $\mathrm{Km}$ values of approximately $260 \mu \mathrm{M}$ and $63 \mu \mathrm{M}$ respectively. A lower $\mathrm{Km}$ of approximately $9 \mu \mathrm{M}$ was observed with $\gamma$-aminobutyraldehyde (GABald), suggesting BAD2 has a higher affinity towards this substate in vivo. The enzyme encoded on chromosome four, BAD1, had optimum activity at $\mathrm{pH} 9.5$, showed little to no affinity towards bet-ald with a $\mathrm{Km}$ of $3 \mathrm{mM}$ and had moderate affinity towards GGBald, NAGABald and GABald with $\mathrm{Km}$ values of approximately 545, 420 and $497 \mu \mathrm{M}$ respectively. BAD1 had a half life roughly double that of BAD2. We discuss the implications of these findings on the pathway of fragrance generation in Basmati and Jasmine
\end{abstract}

L. M. T. Bradbury · S. A. Gillies · D. L. E. Waters ·

R. J. Henry $(\square)$

Centre for Plant Conservation Genetics, Southern Cross

University, Military Road, Lismore, NSW 2480, Australia

e-mail: robert.henry@scu.edu.au

L. M. T. Bradbury · S. A. Gillies · R. J. Henry

Grain Foods CRC, Southern Cross University, Lismore,

NSW 2480, Australia

D. J. Brushett

Centre for Phytochemistry and Pharmacology, Southern Cross

University, Lismore, NSW 2480, Australia rice and the potential of rice to accumulate the osmoprotectant glycine betaine.

Keywords Aminoaldehyde dehydrogenase .

Betaine aldehyde dehydrogenase - Basmati · Rice .

Fragrance $\cdot$ Jasmine

\section{Introduction}

Jasmine and basmati style rice has a pleasant aroma due to the accumulation of the volatile compound 2-acetyl-1pyrroline (2AP) (Buttery et al. 1983a; Lorieux et al. 1996; Widjaja et al. 1996; Yoshihashi 2002a) in all aerial parts of the plant including the leaves and grain (Yoshihashi et al. 2002b). As well as being the major chemical component of fragrance in rice (Buttery et al. 1983a), 2AP is a significant aroma chemical in a number of organisms and foodstuffs including Pandanus (Buttery et al. 1983b; Laohakunjit and Noomhorm 2004; Thimmaraju et al. 2005), popcorn (Schieberle 1995), corn tortillas (Buttery and Ling 1995), baguettes (Zehentbauer and Grosch 1998), ham (Carrapiso et al. 2002), cheese (Zehentbauer and Reineccius 2002), mung bean (Brahmachary and Ghosh 2002), green tea (Kumazawa and Masuda 2002), bread flowers (Vallaris glabra Ktze) (Wongpornchai et al. 2003) some yeasts (Snowdon et al. 2006) and select bacteria (Romanczyk et al. 1995; Costello et al. 2001; Rungsardthong and Noomhoom 2005; Snowdon et al. 2006; Adams and De Kimpe 2007) including the wine spoilage bacteria Lactobaccillus hilgardii (Costello et al. 2001; Snowdon et al. 2006).

Studies into the biological formation of 2AP have shown it can be derived from either proline or ornithine in rice (Yoshihashi et al. 2002b), Pandanus (Thimmaraju et al. 
2005) and L. hilgardii (Costello et al. 2001). In rice the nitrogen in the pyrroline ring of proline becomes the nitrogen in the pyrroline ring of $2 \mathrm{AP}$ while the carboxyl group of proline is removed and replaced with an acetyl group from another source (Yoshihashi et al. 2002b). Costello et al. (2001) found that in L. hilgardii the acetyl group of $2 \mathrm{AP}$ can be derived from fructose when either ethanol or acetaldehyde are supplied in excess. They further suggested $\Delta^{1}$ pyrroline, a product of proline catabolism via putrescine oxidation, is the immediate precursor of the pyrroline ring of $2 \mathrm{AP}$ and the acetyl group was most likely formed from reaction with acetyl-CoA or acetaldehyde in either a chemical or enzymatic reaction. Additionally, detailed precursor studies have revealed that the formation of $2 \mathrm{AP}$ in Bacillus cerus proceeds via acetylation of $\Delta^{1}$ pyrroline (Adams and De Kimpe 2007).

Several independent lines of evidence suggest the genetic cause of rice fragrance is due to the loss of function of the betaine aldehyde dehydrogenase (BAD) homolog. Fragrance is a recessive trait (Lorieux et al. 1996; Garland et al. 2000; Jin et al. 2003) which suggests it is a loss, rather than gain, of gene function that is responsible for fragrance. Several mapping studies have independently identified BAD2 as the candidate gene responsible for fragrance (Bradbury et al. 2005a, b; Vanavichit et al. 2006; Amarawathi et al. 2008; Shi et al. 2008) and sequencing of BAD2 in each case found a deletion within the gene which would render the gene non-functional. Bradbury et al. (2005a) identified an eight base pair deletion in BAD2 which leads to the generation of a premature stop codon that would, if translated, produce a truncated non-functional protein. A variation of this deletion was reported in some Basmati varieties where a five base pair deletion was present at the same location in exon eight rather than the eight base pair deletion (Amarawathi et al. 2008) and Shi et al. (2008) identified a seven base pair deletion in exon two that also renders the BAD2 gene product non-functional and generates fragrance. The accumulated data shows that the generation of fragrance in rice is due to loss of function of the BAD2 gene product and not due to gain of a novel function.

Betaine aldehyde dehydrogenase is an enzyme capable of converting betaine aldehyde (bet-ald), a product of choline oxidation, into the osmoprotectant glycine betaine (Ishitani et al. 1993; Russell et al. 1998; Shirasawa et al. 2006), however, reports of BADs in non glycine betaine accumulating species, including rice, (Ishitani et al. 1993; Nakamura et al. 1997; Mohanty et al. 2002; Niu et al. 2007) suggest BAD enzymes have a role other than the generation of glycine betaine. Many recent studies have found plant BADs are capable of metabolising a range of substrates including omega-aminoaldehydes, often more efficiently than bet-ald (Trossat et al. 1997; Incharoensakdi et al. 2000; Livingstone et al. 2003; Oishi and Ebina 2005), while others report enzymes with aminoaldehyde dehydrogenase (AAD) activity that have high homology to BADs but no affinity for bet-ald (Sebela et al. 2000), leading to the suggestion BADs and AADs are the same enzyme and should be reclassified as such (Sebela et al. 2000; Livingstone et al. 2003; Reumann 2004).

Some of the chemicals other than bet-ald that are substrates of BADs and AADs include; 3-aminopropanaldehyde, 3-dimethylsulfoniopropionaldehyde, $\gamma$-guanidinobutyraldehyde (GGBald) and $\gamma$-aminobutyraldehyde (GABald) (Trossat et al. 1997; Incharoensakdi et al. 2000; Sebela et al. 2000; Oishi and Ebina 2005). The latter of these, GABald, is a four carbon aminoaldehyde derived from proline via putrescine oxidation that in solution exists in equilibrium with its cyclic form, $\Delta^{1}$-pyrroline (Struve and Christophersen 2003), a precursor of $2 \mathrm{AP}$ in B. cerus (Adams and De Kimpe 2007). GABald is the immediate precursor of $\gamma$-aminobutyric acid (GABA) a four carbon amino acid that purportedly plays a role as a natural pesticide (Shelp et al. 2006) and has been shown to play a role in pollen tube growth and guidance (Palanivelu et al. 2003).

It seems plausible that the cDNAs annotated as encoding enzymes with BAD activity in rice, BAD1 and BAD2, actually encode enzymes with AAD activity and that inactivation of $\mathrm{BAD} 2$, encoded from chromosome eight, leads to the accumulation of GABald $/ \Delta^{1}$-pyrroline, the immediate precursor of $2 \mathrm{AP}$. In order to explore this question further, BAD1 and BAD2 cDNAs were isolated and expressed in $E$. coli and the purified enzymes analysed for affinity to a range of substrates including bet-ald and GABald.

\section{Materials and methods}

\section{Plant materials and RNA extraction}

Oryza sativa cv. Nipponbare was obtained as seed from the Australian Plant DNA Bank (www.biobank.com) and grown in sterile tap water for two to four weeks before extraction of total RNA using a Qiagen RNeasy ${ }^{\circledR}$ Plant Mini Kit (50) according to the manufacturer's instructions. Total RNA quantity and quality was assessed by gel electrophoresis and absorbance at $260 \mathrm{~nm}$. Prior to cDNA synthesis, total RNA was incubated for $30 \mathrm{~min}$ at $25^{\circ} \mathrm{C}$ with $1 \mathrm{U}$ DNase (Roche)/ $\mu \mathrm{g}$ RNA in a 1/10th volume $10 \times$ DNase 1 reaction buffer (Invitrogen).

cDNA synthesis

First strand cDNA synthesis utilised the Transcriptor ${ }^{\mathrm{TM}}$ First Strand cDNA synthesis Kit (Roche, Mannheim, Germany) 
according to the manufacturer's instructions. Reactions contained $0.5-1 \mu \mathrm{g}$ total RNA, 10U Transcriptor ${ }^{\mathrm{TM}}$ reverse transcriptase and $50 \mathrm{pmol}$ Anchored-oligo(dT) ${ }_{18}$ primer supplied with the kit. Reactions were incubated at $55^{\circ} \mathrm{C}$ for $30 \mathrm{~min}$ and stopped by incubating at $85^{\circ} \mathrm{C}$ for $5 \mathrm{~min}$. Subsequent PCR amplification used between $1 \mu \mathrm{l}$ and $5 \mu \mathrm{l}$ of the first strand cDNA per $50 \mu \mathrm{l}$ reaction.

PCR amplification and cloning

As BAD1 and BAD2 have previously been identified as full length cDNAs of known sequence, both were initially amplified in two halves utilising the primers $5^{\prime}$ CCAAGGTCCGGGACAAC- $3^{\prime}$ and $5^{\prime}$-GCACCGGCA CATCTTGCTGT- $3^{\prime}$ for the first half of BAD1, $5^{\prime}$-TAG CTTCACATCCCCATGTG- $3^{\prime}$ and $5^{\prime}$-TTCTGTCCGT CCGTTCTG- $3^{\prime}$ for the second half of BAD1, 5'-GATGG CCACGGCGATC- $3^{\prime}$ and $5^{\prime}$-TTTCTCCAGATGCTTGG GTC- $3^{\prime}$ for the first half of BAD2 and $5^{\prime}$-CTGGTAAAA AGATTATGGCTTCA-3' ${ }^{\prime}$ and $5^{\prime}$-CCGTCATACTATGGC CTCTTA- $3^{\prime}$ for the second half of BAD2. These products were then used in a PCR amplification of the full length cDNAs using primers which contained Nde1 and BamH1 restriction sites. BAD1 full-length cDNA was amplified by PCR using the sense primer 5'-ATATCCATATGAT GGCCGCGCCGTCGGCGATCCC- $3^{\prime}$ and antisense primer $5^{\prime}$-AATTCGGATCCTGACGTGCTCCGTCGCTCT TG-3'. BAD2 full-length cDNA was amplified by PCR using the sense primer $5^{\prime}$-ATATCCATATGATGGC CACGGCGATCCCGCAG- $3^{\prime}$ and antisense primer $5^{\prime}$-AA TTCGGATCCACGATCAGAACAGATGGGCGTGTC- $3^{\prime}$. PCRs were performed using Platinum ${ }^{\circledR}$ Taq DNA Polymerase High Fidelity from Invitrogen ${ }^{\mathrm{TM}}$. Reactions contained $0.2 \mu \mathrm{M}$ of each primer, $2 \mu \mathrm{l}$ cDNA, $2 \mathrm{mM}$ $\mathrm{MgSO}_{4}, 5 \%$ DMSO, 3\% glycerol and 2 units of HiFi Taq in $1 \times$ buffer to a volume of $50 \mu \mathrm{l}$. Thermal cycling parameters were as follows: $94^{\circ} \mathrm{C}, 2 \mathrm{~min}$ for one cycle; $94^{\circ} \mathrm{C}, 30 \mathrm{~s}$; $58^{\circ} \mathrm{C}, 30 \mathrm{~s} ; 68^{\circ} \mathrm{C}, 1 \mathrm{~min} 40 \mathrm{~s}$ for 30 cycles. Analysis of PCR products on a $1 \%$ agarose gel revealed single bands of appropriate size. Prior to ligation into pGEM $^{\circledR}-\mathrm{T}$ vector (Promega), A overhangs were added by incubation of cDNAs with $5 \mathrm{mM}$ dATP, $1 \times$ PCR buffer $5 \mathrm{mM} \mathrm{MgCl}_{2}$ and Platinum Taq DNA polymerase at $95^{\circ} \mathrm{C}$ for $5 \mathrm{~min}$ followed by $70^{\circ} \mathrm{C}$ for $30 \mathrm{~min}$. Following ligation into pGEM $^{\circledR}$-T (Promega) restriction digests with Nde1 and BamH1 were performed which allowed directional cloning into $\mathrm{pET}-19 \mathrm{~b}$ expression vector (Novagen) following the manufacturer's instructions.

\section{Sequencing}

Cloned cDNAs were sequenced using the BigDye ${ }^{\circledR}$ Terminator v3.1 Cycle Sequencing Kit (Applied Biosystems,
Foster, CA., USA) and the labelled DNA fragments separated and analysed with an ABI 373048 capillary DNA analyser (Applied Biosystems). All sequence analysis and alignments were undertaken using ChromasPro software (Technelysium Pty Ltd).

Recombinant protein expression and purification

Full length BAD1 and BAD2 cDNAs were directionally cloned into the Nde1 and BamH1 restriction sites of the bacterial expression plasmid pET19b (Novagen) to enable addition of a $10 \times$ Histidine tag to the $\mathrm{C}$ terminus of both enzymes. E. coli strain BL21 (Novagen, Madison, WI, USA) was transformed with the pET19b-BAD1 and pET19b-BAD2 vector constructs and grown in LuriaBertani medium supplemented with appropriate antibiotics according to the manufacturer's instructions. One hundred $\mathrm{ml}$ of an overnight culture was transferred to $500 \mathrm{ml}$ fresh Luria-Bertani medium and grown for a further $3 \mathrm{~h}$. The expression of recombinant protein was then induced by the addition of $1 \mathrm{mM}$ isopropyl $\beta$-D-thiogalactoside (IPTG) and the cells were allowed to grow for a further $3 \mathrm{~h}$ at $37^{\circ} \mathrm{C}$ with shaking $(210 \mathrm{rpm})$ before harvesting by centrifugation at $4^{\circ} \mathrm{C}$. The cells were lysed in lysis/bind buffer $(300 \mathrm{mM} \mathrm{NaCl}, 50 \mathrm{mM}$ sodium phosphate buffer ( $\mathrm{pH}$ 8.0), $10 \mathrm{mM}$ imidazole, 1/10th volume $10 \times$ BugBuster $^{\circledR}$ Protein Extraction Reagent (Novagen, Darmstadt, Germany), Complete, EDTA-free protease inhibitor cocktail (Roche, Mannheim, Germany), $100 \mu \mathrm{M}$ sodium orthovanadate, $100 \mu \mathrm{M}$ sodium molybdate and $100 \mu \mathrm{M}$ sodium tartrate. Insoluble material was pelleted by centrifugation at $15,000 \mathrm{~g}$ for $30 \mathrm{~min}$ at $4^{\circ} \mathrm{C}$ and the resulting supernatant was incubated on ice in the presence of $500 \mu \mathrm{l} \mathrm{Ni-NTA} \mathrm{His \cdot Bind}{ }^{\circledR}$ Resin (Novagen) for $60 \mathrm{~min}$ with gentle shaking. The resin was washed $5 \times$ in $10 \mathrm{ml}$ wash buffer $(300 \mathrm{mM} \mathrm{NaCl}, 50 \mathrm{mM}$ sodium phosphate buffer, $20 \mathrm{mM}$ imidazole, $\mathrm{pH} 8.0$ ) to remove contaminating proteins. Recombinant His-BAD protein was eluted by $7 \times 500 \mu \mathrm{l}$ washes in elution buffer $(300 \mathrm{mM} \mathrm{NaCl}$, $50 \mathrm{mM}$ sodium phosphate buffer, $250 \mathrm{mM}$ imidazole, $\mathrm{pH}$ 8.0). Elutions were pooled and dialysed against $50 \mathrm{mM}$ HEPES buffer ( $\mathrm{pH} 7.5)$ for $24 \mathrm{~h}$ at $4^{\circ} \mathrm{C}$. Following dialysis the protein was concentrated 10 fold by centrifugation using a $12-14 \mathrm{kDa}$ cut-off spin column and stored at $-80^{\circ} \mathrm{C}$ with the addition of $10 \%$ glycerol. The presence of recombinant protein was confirmed by SDS/PAGE.

Synthesis of substrates

Betaine aldehyde was obtained from Sigma-Aldrich. GABald/ $\Delta^{1}$-pyrroline was synthesised to $86 \%$ purity by the method of Struve and Christophersen (2003). GGBald was synthesised by a modification of the method of Vanderbilt 
et al. (1975) by bubbling nitrogen gas through a $20 \mathrm{ml}$ $(1.0 \mathrm{mmol})$ solution of arginine in water for $5 \mathrm{~min}$, heating to $30^{\circ} \mathrm{C}$ before adding, while mixing, chloramine-T hydrate to a concentration of $1.0 \mathrm{mmol}$. This mixture was incubated at $30^{\circ} \mathrm{C}$ for $30 \mathrm{~min}$, cooled on ice and filtered. The filtrate was then purified to $81 \%$ by separation on a preparative Phenomenex LunaC18 100A, 5u, $150 \times 25.4 \mathrm{~mm}$ I.D. HPLC column using Gilson 306 gradient pumps, Gilson 155 UV/Vis detector, Gilson 204 fraction collector and controlled using Gilson Unipoint software. The mobile phase was an acetonitrile/water mixture with $0.05 \%$ trifluoroacetic acid, at a flow rate of $15 \mathrm{ml} / \mathrm{min}$ starting at $1 \%$ acetonitrile and holding for 5 min before ramping up to $90 \%$ acetonitrile over $15 \mathrm{~min}$. Selected fractions were pooled and dried under vacuum on a BÜCHI Rotorvapor R-114 rotary evaporator. NAGABald diethyl acetal was synthesised by modification of the method of Rajabi and Saidi (2005). Briefly, $250 \mu \mathrm{l}$ of GABald diethylacetal was mixed with an equimolar volume of acetic anhydride and microwaved (on high) for $5 \times 3 \mathrm{~s}$. The diethylacetal groups were removed by the method of Struve and Christophersen (2003) to leave NAGABald of $73 \%$ purity as determined by LCMS.

Purity of GGBald and NAGABald was assessed by LCMS using a Phenomenex AquaC18 125A, 5u, $150 \times 4.6 \mathrm{~mm}$ I.D. HPLC column on an Agilent $1100 \mathrm{LC}$ and an Agilent 1100 MSD controlled by chemstation software. The mobile phase was an acetonitrile/water mix with $0.05 \%$ trifluoroacetic acid, at a flow rate of $1 \mathrm{ml} / \mathrm{min}$ starting at $1 \%$ acetonitrile and holding for $5 \mathrm{~min}$ before ramping up to $90 \%$ acetonitrile over $15 \mathrm{~min}$. The MS was run in atmospheric pressure chemical ionisation (APCI) mode, had an ionisation voltage of $150 \mathrm{~V}$, capillary voltage of $2000 \mathrm{~V}$, drying gas temperature of $345^{\circ} \mathrm{C}$, vaporiser temperature of $395^{\circ} \mathrm{C}$, nebuliser pressure of $60 \mathrm{psig}$ and a gas flow rate of $5 \mathrm{l} / \mathrm{min}$. The purity of $\Delta^{1}$-pyrroline was assessed on an Agilent 6890 Series GC system with an Agilent 5973 Network Mass Selective Detector using an SGE BPX5 capillary column $50.0 \mathrm{~m} \times 0.22 \mathrm{~mm}$ ID $\times 1 \mu \mathrm{m}$ film thickness. One $\mu \mathrm{l}$ of sample was injected at an inlet temperature of $280^{\circ} \mathrm{C}$ and $25: 1$ split ratio. Helium was used as the carrier gas with a constant flow of $1.5 \mathrm{ml} / \mathrm{min}$. The oven was held at $50^{\circ} \mathrm{C}$ for $5 \mathrm{~min}$ before ramping up to $300^{\circ} \mathrm{C}$ at a rate of $4^{\circ} \mathrm{C} / \mathrm{min}$.

\section{Enzyme assay}

Enzyme assay mixtures ( $1 \mathrm{ml}$ total volume) were based on the work of Yorifuji et al. (1986), Trossat et al. (1997), Valenzuela-Soto et al. (2003) and Oishi and Ebina (2005) and contained $50 \mathrm{mM}$ HEPES, MES or Glycine Buffer, $20 \mathrm{mM} \beta$-mercaptoethanol, $2 \mathrm{mM} \mathrm{NAD}+$, with $10 \mathrm{ug}$ of enzyme (BAD1 or BAD2) and varying concentrations of substrates. HEPES and MES buffers were obtained from Sigma, glycine buffer consisted of $50 \mathrm{mM}$ glycine, $1 \mathrm{mM}$ $\mathrm{MgSO}_{4}, 0.1 \mathrm{mM} \mathrm{ZnSO}$. Buffers were adjusted to the required $\mathrm{pH}$ by addition of $\mathrm{KOH}$. The reaction was followed by monitoring the conversion of NAD + to NADH $(340 \mathrm{~nm})$ on a Hewlett Packard 8453 UV/vis spectrophotometer controlled by ChemStation software. For determination of optimum $\mathrm{pH}, 5 \mathrm{mM}$ GABald was used as the final substrate concentration and this was confirmed by replacing GABald with $5 \mathrm{mM}$ bet-ald as the final substrate concentration. All enzyme assays were performed a minimum of three times.

\section{Results}

Purification of recombinant rice BADs expressed in E. coli

SDS gel analysis showed rice BAD1 and BAD2 purified from $E$. coli have subunits of approximately $56 \mathrm{kDa}$. Final enzyme concentrations were adjusted to $10 \mu \mathrm{g} / \mu \mathrm{l}$ as determined by Bradford assay.

Synthesis of aldehyde substrates

Purity of synthesised substrates was analysed via GCMS. The GABald preparation displayed two main peaks with molecular weights of 69 and 87 corresponding to the circular $\Delta^{1}$-pyrroline form and the linear GABald form respectively. Likewise the $\mathrm{N}$-acetyl- $\gamma$-aminobutyraldehyde (NAGABald) preparation showed a large peak with a molecular weight of 129 corresponding to the linear form of NAGABald and a smaller peak with a molecular weight of 113 corresponding to the circular form $\mathrm{N}$-acetylpyrroline. $\Delta^{1}$-pyrroline was taken to be $86 \%$ pure based on the method of Struve and Christophersen (2003) while GGBald and NAGABald were determined by GCMS and LCMS analysis to be $81 \%$ and $73 \%$ pure respectively.

\section{$\mathrm{pH}$ optimum and half life of BADs}

Bet-ald was used for optimal $\mathrm{pH}$ determination of BAD1 and BAD2 as it is the only substrate tested that does not undergo major structural rearrangement (cyclisation) which may effect substrate specificity under differing $\mathrm{pH}$. Optimum activity of BAD1 and BAD2 towards bet-ald at room temperature was found to be at $\mathrm{pH} 9.5$ and $\mathrm{pH} 10$ respectively (Fig. 1). In the absence of beta-mercaptoethanol the half life of BAD1 at $\mathrm{pH} 9.5$ at room temperature was shown to be approximately $10 \mathrm{~min}$ while $\mathrm{BAD} 2$ at $\mathrm{pH} 9.5$ at room temperature had a half life of approximately $5 \mathrm{~min}$ (Figs. 2, 3). 
Fig. 1 Relative activity of BAD1 and BAD2 enzymes
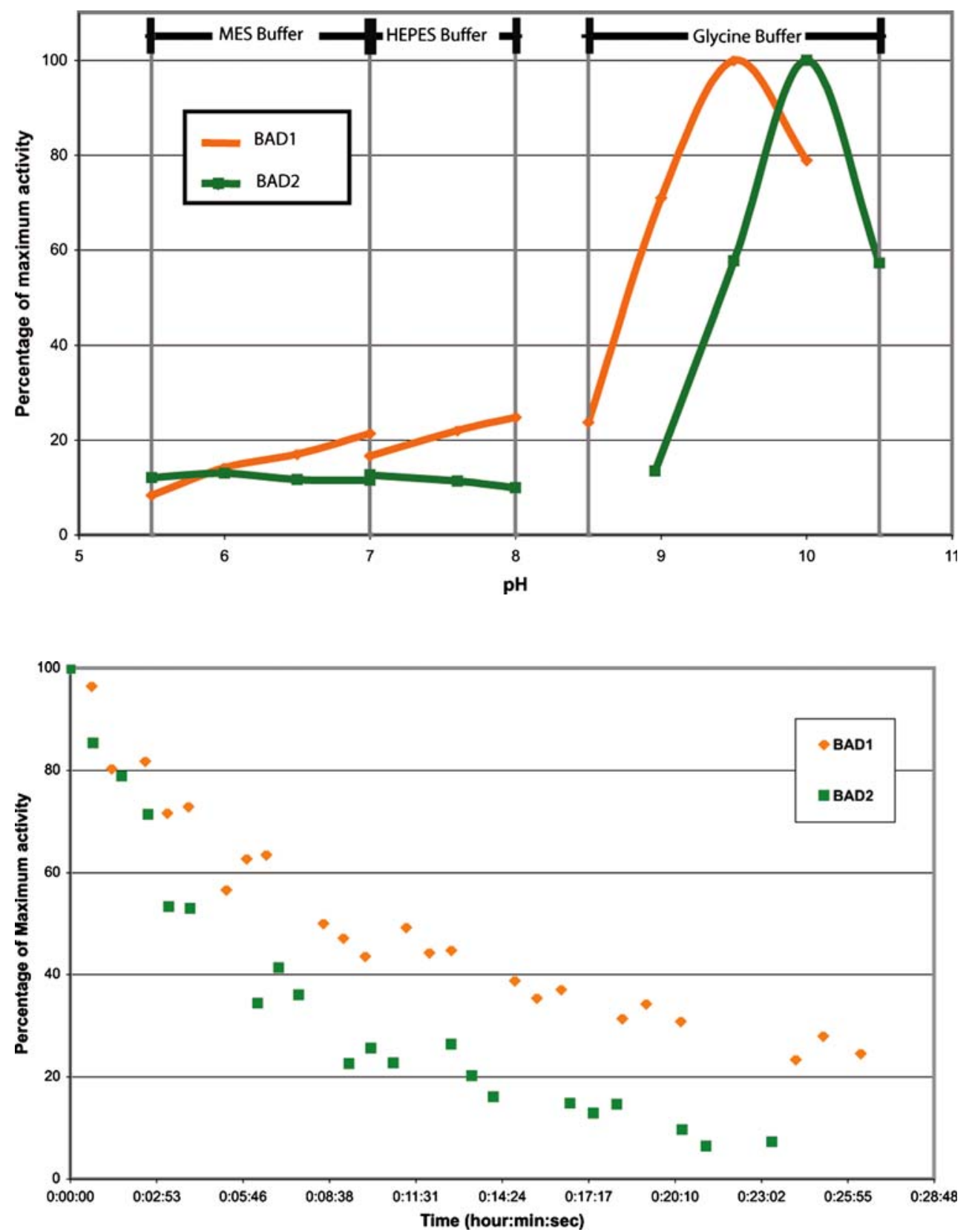

Fig. 2 Relative activity of BAD1 and BAD2 at $\mathrm{pH} 9.5$ after pre-incubation at room temperature (greater specificity) for NAGABald $(420 \mu \mathrm{M})$ than it does for GGBald (545 $\mu \mathrm{M})$. Compared to BAD2, BAD1 showed higher $\mathrm{Km}$ values (lower specificity) to most substrates with the exception of $\mathrm{N}$-acetyl-pyrroline.

\section{Discussion}

Enzyme half life and $\mathrm{pH}$ optima

In the absence of beta-mercaptoethanol the half life of BAD1 was approximately ten minutes while BAD2 had a half life of approximately five minutes. This stability 
Fig. 3 BAD1 and BAD2 at $\mathrm{pH}$ 9.5 incubated at room temperature before assay versus inverse relative activity

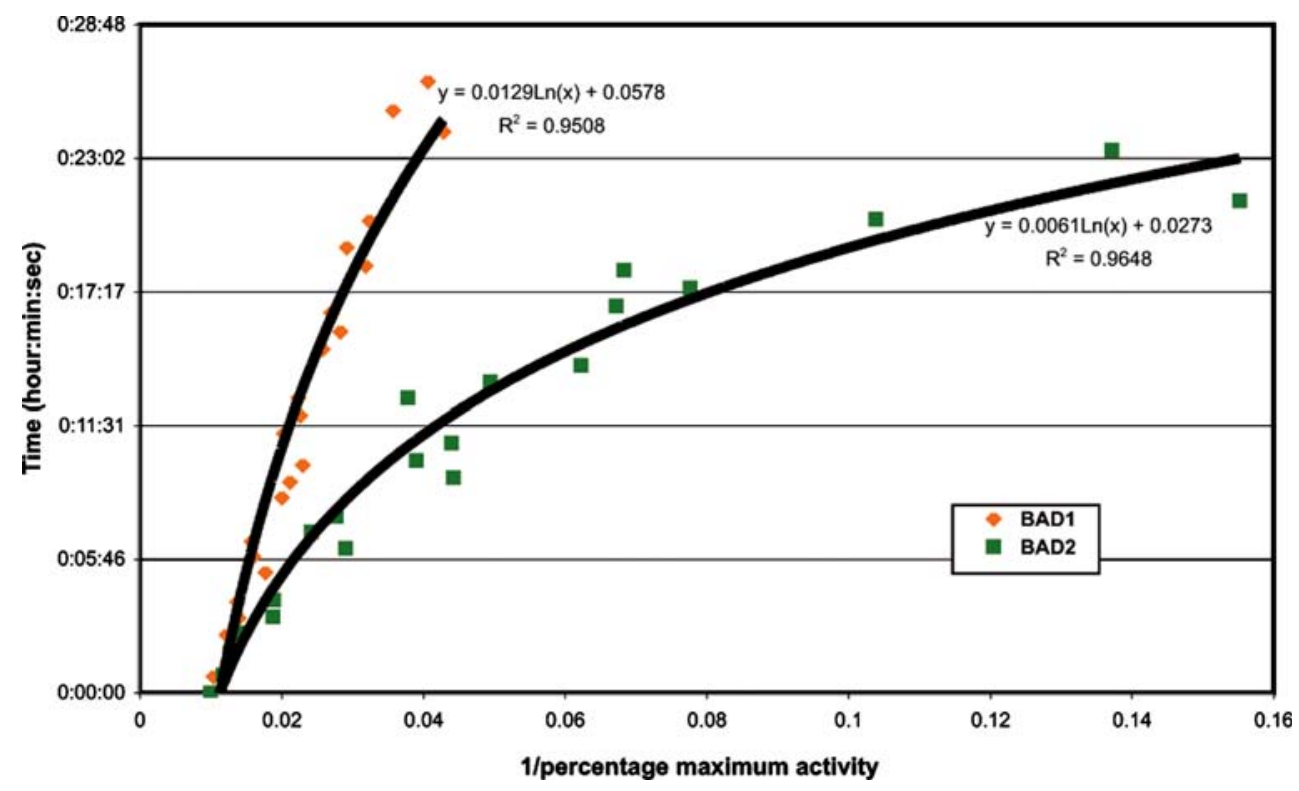

Table $1 \mathrm{Km}$ and $\mathrm{kcat} / \mathrm{Km}$ values of BAD1 and BAD2 at optimum $\mathrm{pH}$ towards various substrates

\begin{tabular}{|c|c|c|c|c|}
\hline \multirow[t]{2}{*}{ Substrate } & \multicolumn{2}{|c|}{ Enzyme $\mathrm{Km}(\mu \mathrm{M})$} & \multicolumn{2}{|c|}{ Enzyme kcat/Km $\left(\mathrm{M}^{-1} \mathrm{~s}^{-1}\right)$} \\
\hline & BAD1 & BAD2 & BAD1 & BAD2 \\
\hline Betaine aldehyde & 3233 & 63 & 0.1 & 2 \\
\hline$\gamma$-Aminobutyraldehyde $/ \Delta^{1}$-pyrroline & 498 & 9 & 27 & 68 \\
\hline$\gamma$-Guadinoaminobutyraldehyde & 545 & 32 & 11 & 5 \\
\hline $\mathrm{N}$-acetyl- $\gamma$-aminobutyraldehyde/ $\mathrm{N}$-acetyl-pyrroline & 420 & 10,608 & 2 & 0.1 \\
\hline 2-Acetyl-1-pyrroline & - & - & - & - \\
\hline
\end{tabular}

difference could lead to an overestimation of the concentration of active BAD2 enzyme in comparison to BAD1 in corresponding assays, leading to an underestimation of BAD2 activity. This would not affect the reported $\mathrm{Km}$ values but would lead to larger $\mathrm{kcat} / \mathrm{Km}$ values suggesting that our estimates of BAD2 $\mathrm{kcat} / \mathrm{Km}$ are conservative.

Optimum activity of BAD1 and BAD2 towards bet-ald was found to be at $\mathrm{pH} 9.5$ and $\mathrm{pH} 10$ respectively. High $\mathrm{pH}$ optima have been reported for many $\mathrm{AAD}$ and $\mathrm{BAD}$ enzymes including BAD from oats (Livingstone et al. 2003), Zoysia tenuifolia (Oishi and Ebina 2005) and AAD from pea (Sebela et al. 2000). Both rice BAD1 and BAD2 are believed to be directed to the peroxisome (Nakamura et al. 1997; Bradbury et al. 2005a). Although no data are available on the $\mathrm{pH}$ of plant peroxisomes, Dansen et al. (2000) has shown that human fibroblast peroxisomes have a basic $\mathrm{pH}$ of around $8.2 \pm 0.3$. Struve and Christophersen (2003) investigated the influence of $\mathrm{pH}$ on structural forms of GABald and found that at pHs of 9-10 GABald exists almost entirely as the ring form, $\Delta^{1}$-pyrroline, and so BAD enzymes may therefore be active toward the ring form of this aldehyde. Alternatively, BADs may be active towards the linear form, GABald, which at high $\mathrm{pH}$ would have existed in the reaction mixture at very low concentrations. If this is the case, the $\mathrm{Km}$ values of both BADs towards the linear GABald would be significantly lower than those reported here. Studies on 2AP formation from proline in Maillard reactions have shown more $2 \mathrm{AP}$ is formed at $\mathrm{pH} 8$ than is formed at $\mathrm{pH} 6$ (Blank et al. 2003) suggesting a possible link between BAD location, GABald $/ \Delta^{1}$-pyrroline isomeric form and $2 \mathrm{AP}$ formation.

Role of BAD2 and GABald accumulation in fragrance

Radio-labelling studies have shown the nitrogen in the pyrroline ring of proline becomes the nitrogen in the pyrroline ring of fragrant rice 2AP (Yoshihashi et al. 2002b). The compound $\Delta^{1}$-pyrroline is identical to the ring component of $2 \mathrm{AP}$ and has been shown to be a precursor of 2AP in Maillard reactions (Hofmann and Schieberle 1998) and more recently in B. cereus (Adams and De Kimpe 2007). $\Delta^{1}$-pyrroline exists in equilibrium with its linear form of GABald which is part of the proline catabolism pathway via oxidation of putrescine. GABald has been 
shown to be a substrate of BADs and AADs from various plants (Trossat et al. 1997; Sebela et al. 2000; Livingstone et al. 2003; Oishi and Ebina 2005) and a non-functional BAD2 is responsible for fragrance in rice (Bradbury et al. 2005a, b; Vanavichit et al. 2006; Amarawathi et al. 2008; Shi et al. 2008). Because of the associations between $\Delta^{1}$ pyrroline and 2AP and between GABald and BADs as well as the ability of GABald to spontaneously cyclise into $\Delta^{1}$ pyrroline, we focused on GABald as our primary substrate of interest. The other aldehyde substrates were chosen because of their similarity to GABald and occurrence in related pathways of proline/arginine catabolism. Bet-ald was chosen because of the homology based annotation of the gene responsible for fragrance in rice (Bradbury et al. 2005a).

Both BAD enzymes showed greater affinity $(\mathrm{Km})$ and higher catalytic efficiency $(\mathrm{kcat} / \mathrm{Km})$ towards the aminoaldehydes GABald and GGBald than they did towards bet-ald as shown by the lower $\mathrm{Km}$ values and higher kcat/ $\mathrm{Km}$ values for GABald and GGBald (Table 1). This suggests the annotation of the two enzymes as BADs, which is based on sequence homology to BADs of other plants, is not the most appropriate annotation and the annotation of AAD would be more accurate in defining their in vitro activity. Of the substrates analysed, BAD2 showed greatest affinity towards GABald with a $\mathrm{Km}$ of $9 \mu \mathrm{M}$ and a high $\mathrm{kcat} / \mathrm{Km}$ of $68 \mathrm{M}^{-1} \mathrm{~s}^{-1}$, suggesting GABald is an effective substrate for BAD2 and that accumulation and spontaneous cyclisation of GABald to form $\Delta^{1}$-pyrroline due to a non-functional BAD2 enzyme is a likely cause of $2 \mathrm{AP}$ accumulation in rice. We propose the biochemical pathway of 2AP production in rice (Fig. 4) starts with proline being catabolised via putrescine into GABald, a substrate of BAD2. If BAD2 is present and functional it is able to convert the majority of GABald to $\gamma$-aminobutyric acid (GABA), but if BAD2 is absent or non-functional the majority of GABald is acetylated to form 2AP.

Putrescine is found in high levels in actively growing tissues where cells are rapidly dividing (Kakkar et al. 2000) and is catabolised to GABald by diamine oxidase (DAO) during the processes of lignification and cell wall stiffening (Sebela et al. 2001), after the majority of cell division has taken place. Formation of GABald is therefore likely to occur in young tissue that has stopped actively dividing and is undergoing cell wall stiffening. Tips of rice leaves contain higher levels of 2AP than the base of the leaf (data not shown) while young leaves are more aromatic than old ones (Lorieux et al. 1996), which correlates with the proposed pathway of 2AP formation occurring shortly after putrescine catabolism (Fig. 4). Dissipation of 2AP in older tissue is most likely due to the volatile nature of the chemical (Yoshihashi et al. 2005).
BAD1 has a low affinity to GABald with a $\mathrm{Km}$ of $498 \mu \mathrm{M}$ but a high $\mathrm{kcat} / \mathrm{Km}$ of $27 \mathrm{M}^{-1} \mathrm{~s}^{-1}$ suggesting that despite the large $\mathrm{Km}$, GABald may still be a substrate for $\mathrm{BAD} 1$ in vivo and that the presence of BAD1 may diminish the pool of GABald available to form 2AP. The similarity of preferred substrates of BAD1 and BAD2 makes it unclear as to why a non-functional BAD2 has such a major impact on the fragrance phenotype of rice. Fitzgerald et al. (2008) have shown BAD1 accounts for at most $30 \%$ of total BAD gene expression within the leaves of non-fragrant rice, although this is increased by exposure to salt stress. It is therefore conceivable the fragrance phenotype of rice is altered by the action/inactivation of the BAD2 enzyme via a combination of its higher transcript levels, higher catalytic efficiency and higher substrate specificity towards GABald in comparison to that of BAD1. An absence of BAD2 is likely to cause an accumulation of GABald leading to higher 2AP production.

BAD1 may influence fragrance in rice, especially in saline conditions when BAD1 mRNA expression is higher and, perhaps more importantly, when levels of GABald are closer to that of the Km of BAD1. Lorieux et al. (1996) identified a minor locus for fragrance in rice located on chromosome four most likely between molecular markers RG214 and RG788. These markers are very close to molecular marker RZ675, located at 23,974,544 bp on chromosome four. The gene encoding the BAD1 enzyme is located on chromosome four between $23,146,445$ and 23,150,872 bp (NCBI; http://www.ncbi.nlm.nih.gov/). This fragrance locus had less influence on 2AP accumulation in the varieties studied than BAD2 and it was only identified by Lorieux et al. (1996) when the BAD2 locus on chromosome eight was accounted for. More recent work has further narrowed down this region and suggested a role for BAD1 on the level of fragrance in Basmati rice (Amarawathi et al., 2008). With their similar activities and with BAD1 being associated with a fragrance allele, it seems likely that both BAD1 and BAD2 have an influence on 2AP accumulation in rice. Mutations that lead to a nonfunctional BAD1 or a reduction in expression levels of BAD1 may cause an increase in 2AP accumulation and could explain the minor fragrance allele identified by Lorieux et al. (1996) and Amarawathi et al. (2008).

Does fragrance affect plant performance?

The identification of a perturbation of one of the GABA synthesis pathways being key to $2 \mathrm{AP}$ accumulation in rice leads to the question; does this perturbation lead to a decrease in plant performance? BAD expression has previously been linked to salt tolerance in numerous plants (Ishitani et al. 1995; Harinasut et al. 1996; Wood et al. 1996) and the gene expression of BAD2 (Fitzgerald et al. 
Fig. 4 Pathway from proline to potential substrates (boxed) of BAD1 and BAD2 and to 2acetyl-1-pyrroline via $\Delta^{1}$ pyrroline when BAD2 is inactive (filled arrows) or to GABA when BAD2 is active

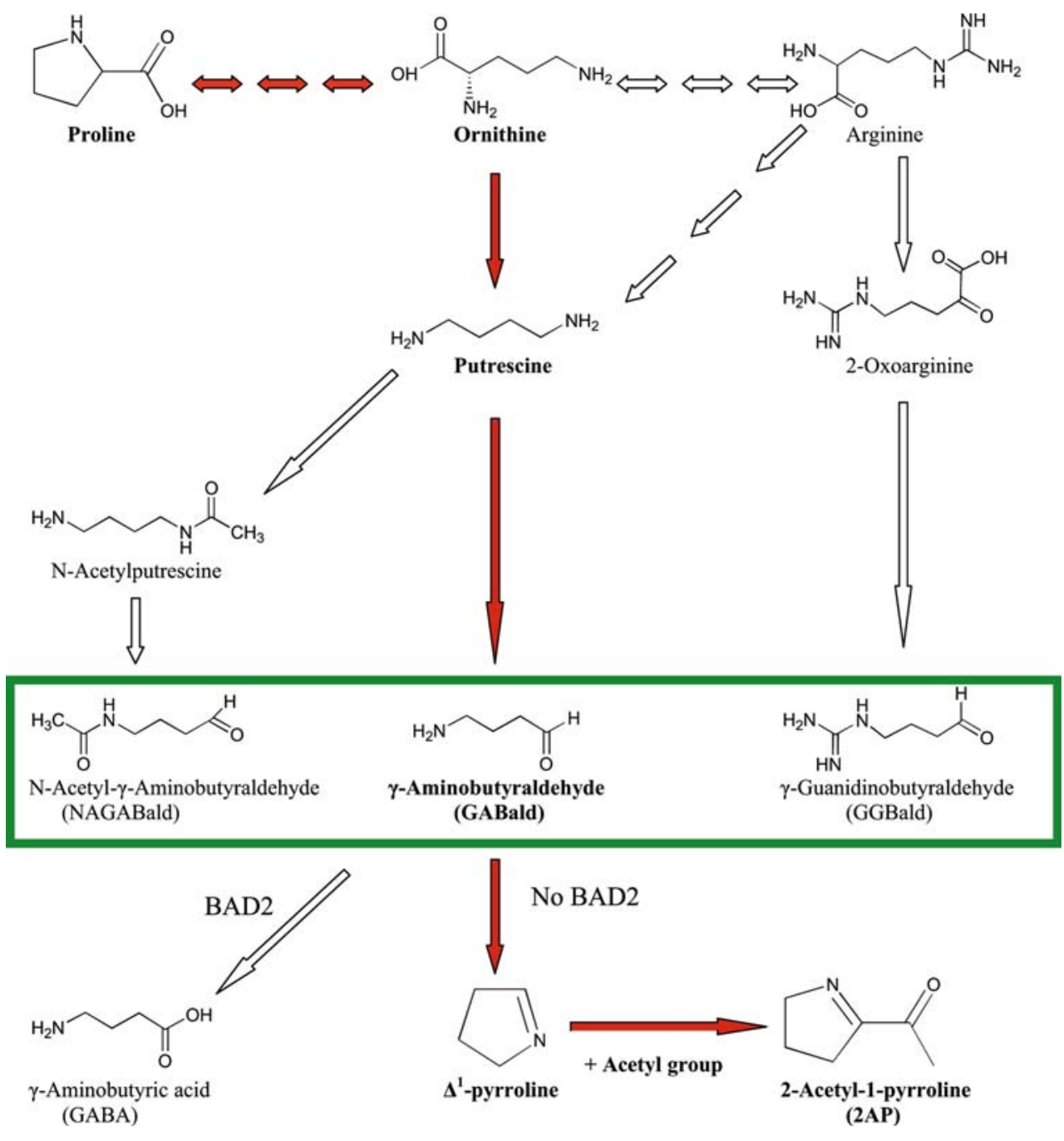

2008) and the concentration of GABA (Kim et al. 2007) has been found to increase in rice under salt stress. BAD2 has been shown to play a role in salt tolerance in rice, yet does not accumulate glycine betaine (Ishitani et al. 1993; Rathinasabapathi et al. 1993) and we have shown that GABald is the preferred substrate of BAD2. The predominant pathway to GABA formation in plants is via direct decarboxylation of glutamate (Narayan and Nair 1990; Snedden et al. 1995) and alternative pathways of GABA synthesis are from either arginine or ornithine decarboxylases via putrescine (Narayan and Nair 1990; Kakkar et al. 2000). A GABA gradiant has been shown to play an essential role in pollen tube growth and guidance in Arabidopsis (Palanivelu et al. 2003) and interruption of this gradient inhibits pollen tube growth. Reports of low yield in fragrant rice parallel reports of sterility in fragrant Pandanus (Stone 1978), a plant that is often grown in environments that are subject to water or salinity stress. BAD2 may play a role in the generation of a GABA gradient in rice panicles, under stress conditions, and disruption of this process may inhibit plant performance, including grain yield.

Betaine aldehyde accumulation

Rice does not accumulate glycine betaine, reportedly because its genome encodes a choline monooxygenase (CMO) that is non-functional due to aberrant stop codons (NCBI accession number P0545E05.33 chromosome 6) (Shirasawa et al. 2006). Although there have been no reports of a CMO being isolated or characterised from any plant in the Poaceae to date (Jagendorf and Takabe 2001; Oishi and Ebina 2005), the NCBI database records the isolation of an apparently complete CMO cDNA from rice (AJ578494) (Niu et al. 2007). If this putative rice CMO is fully functional then a new theory as to why rice does not accumulate glycine betaine is called for. Perhaps rice $\mathrm{CMO}$ is expressed at low levels. Alternatively, CMO and BAD expression maybe spatially or temporally separated, the apparent localisation of $\mathrm{BAD}$ in the peroxisome and $\mathrm{CMO}$ 
in the cytoplasm may separate the pool of the toxic intermediate bet-ald from BAD.

Efforts to engineer glycine betaine accumulation in fragrant rice need to ensure the pool of GABald is maintained at levels which result in the formation of detectable levels of 2AP. This could be achieved by the use of the $\operatorname{cod} A$ gene which produces an enzyme that converts choline directly to glycine betaine, and probably has very low affinity for GABald. Furthermore, targeting this enzyme to the chloroplast could maximise salt tolerance and isolate the action of this enzyme from the pool of GABald, there by maintaining $2 \mathrm{AP}$ levels in fragrant rice while increasing salt tolerance. Transformation of a fragrant rice variety, Pusa Basmati 1, with $\operatorname{cod} A$ has resulted in glycine betaine accumulation and enhanced salt tolerance (Mohanty et al. 2002), however, since the close association between glycine betaine and fragrance was unknown at that time, the effect of $\operatorname{cod} A$ expression on fragrance was not assessed.

\section{Conclusions}

We have shown that two enzymes previously annotated as BADs actually have a greater affinity towards aminoaldehydes and as such should be reclassified AADs. We have demonstrated for the first time the biochemical function of an enzyme produced from a gene which has previously been linked to the fragrance phenotype in rice (Bradbury et al. 2005a). The accumulation of $2 \mathrm{AP}$ in rice is explained by the absence of BAD2 activity leading to an increased level of its preferred substrate, GABald $/ \Delta^{1}$-pyrroline, the immediate precursor of 2AP. This work has also provided insights which are applicable to efforts to engineer glycine betaine accumulation in rice which would enhance stress tolerance.

Open Access This article is distributed under the terms of the Creative Commons Attribution Noncommercial License which permits any noncommercial use, distribution, and reproduction in any medium, provided the original author(s) and source are credited.

\section{References}

Adams A, De Kimpe N (2007) Formation of pyrazines and 2-acetyl1-pyrroline by Bacillus cereus. Food Chem 101:1230-1238. doi: 10.1016/j.foodchem.2006.03.027

Amarawathi Y, Singh R, Singh AK, Singh VP, Mohapatra T, Sharma TR et al (2008) Mapping of quantitative trait loci for basmati quality traits in rice (Oryza sativa L.). Mol Breed 21(1):49-65. doi:10.1007/s11032-007-9108-8

Blank I, Devaud S, Matthey-Doret W, Robert F (2003) Formation of odorants in Maillard model systems based on L-proline as affected by pH. J Agric Food Chem 51:3643-3650. doi: $10.1021 / \mathrm{jf0} 34077 \mathrm{t}$

Bradbury LMT, Fitzgerald TL, Henry RJ, Jin QS, Waters DLE (2005a) The gene for fragrance in rice. Plant Biotechnol J 3:363370. doi:10.1111/j.1467-7652.2005.00131.x
Bradbury LMT, Henry RJ, Jin QS, Reinke RF, Waters DLE (2005b) A perfect marker for fragrance genotyping in rice. Mol Breed 16:279-283. doi:10.1007/s11032-005-0776-y

Brahmachary RL, Ghosh M (2002) Vaginal pheromone and other compounds in mung-bean aroma. J Sci Ind Res (India) 61:625-629

Buttery RG, Ling LC (1995) Volatile flavor components of corn tortillas and related products. J Agric Food Chem 43:1878-1882. doi:10.1021/jf00055a023

Buttery RG, Juliano BO, Ling LC (1983b) Identification of rice aroma compound 2-Acetyl-1-Pyrroline in Pandan Leaves. Chem Ind (Lond) 478-479

Buttery RG, Ling LC, Juliano BO, Turnbaugh JG (1983a) Cooked rice aroma and 2-Acetyl-1-Pyrroline. J Agric Food Chem 31:823-826. doi:10.1021/jf00118a036

Carrapiso AI, Jurado A, Timon ML, Garcia C (2002) Odor-active compounds of Iberian hams with different aroma characteristics. J Agric Food Chem 50:6453-6458. doi:10.1021/jf025526c

Costello PJ, Lee TH, Henschke PA (2001) Ability of lactic acid bacteria to produce $\mathrm{N}$-heterocycles causing mousy off-flavour in wine. Aust J Grape Wine Res 7:160-167. doi:10.1111/ j.1755-0238.2001.tb00205.x

Dansen TB, Wirtz KWA, Wanders RJA, Pap EHW (2000) Peroxisomes in human fibroblasts have a basic $\mathrm{pH}$. Nat Cell Biol 2:5153. doi:10.1038/71375

Fitzgerald TL, Waters DLE, Henry RJ (2008) The affect of salt on betaine aldehyde dehydrogenase transcript levels and 2-acetyl-1pyrroline concentration in fragrant and non-fragrant rice (Oryza sativa). Plant Sci. doi:10.1016/j.plantsci.2008.06.005

Garland S, Lewin L, Blakeney A, Reinke R, Henry R (2000) PCRbased molecular markers for the fragrance gene in rice (Orysa sativa). Theor Appl Genet 101:364-371. doi:10.1007/s001 220051492

Harinasut P, Tsutsui K, Takabe T, Nomura M, Takabe T, Kishitani S (1996) Exogenous glycine betaine accumulation and increased salt-tolerance in rice seedlings. Biosci Biotechnol Biochem 60:366-368

Incharoensakdi A, Matsuda N, Hibino T, Meng YL, Ishikawa H, Hara A et al (2000) Overproduction of spinach betaine aldehyde dehydrogenase in Escherichia coli. Structural and functional properties of wild-type, mutants and E. coli enzymes. Eur J Biochem 267:7015-7023. doi:10.1046/j.1432-1327.2000.01797.x

Hofmann T, Schieberle P (1998) 2-Oxopropanal, hydroxy-2-propanone, and 1-pyrroline important intermediates in the generation of the roast-smelling food flavor compounds 2-acetyl-1-pyrroline and 2-acetyltetrahydropyridine. J Agric Food Chem 46:2270 2277. doi:10.1021/jf970990g

Ishitani M, Arakawa K, Mizuno K, Kishitani S, Takabe T (1993) Betaine aldehyde dehydrogenase in the Gramineae. Levels in leaves of both betaine accumulating and non-accumulating cereal plants. Plant Cell Physiol 34:493-495

Ishitani M, Nakamura T, Han SY, Takabe T (1995) Expression of the betaine aldehyde dehydrogenase gene in barley in response to osmotic stress and abscisic acid. Plant Mol Biol 27:307-315. doi: 10.1007/BF00020185

Jagendorf TA, Takabe T (2001) Inducers of glycine betaine synthesis in barley. Plant Physiol 127:1827-1835. doi:10.1104/ pp.127.4.1827

Jin QS, Waters D, Cordeiro GM, Henry RJ, Reinke RF (2003) A single nucleotide polymorphism (SNP) marker linked to the fragrance gene in rice (Oryza sativa L.). Plant Sci 165:359-364. doi:10.1016/S0168-9452(03)00195-X

Kakkar RK, Nagar PK, Ahuja PS, Rai VK (2000) Polyamines and plant morphogenesis. Biol Plant 43:1-11. doi:10.1023/ A: 1026582308902

Kim DW, Shibato J, Agrawal GK, Fujihara S, Iwahashi H, Kim DH et al (2007) Gene transcription in the leaves of rice undergoing 
salt-induced morphological changes (Oryza sativa L.). Mol Cells 24:45-59

Kumazawa K, Masuda H (2002) Identification of potent odorants in different green tea varieties using flavor dilution technique. J Agric Food Chem 50:5660-5663. doi:10.1021/jf020498j

Laohakunjit N, Noomhorm A (2004) Supercritical carbon dioxide extraction of 2-acetyl-1-pyrroline and volatile components from Pandan leaves. Flavour Fragrance J 19:251-259. doi:10.1002/ ffj. 1297

Livingstone JR, Maruo T, Yoshida I, Tarui Y, Hirooka K, Yamamoto $\mathrm{Y}$ et al (2003) Purification and properties of betaine aldehyde dehydrogenase from Avena sativa. J Plant Res 116:133-140

Lorieux M, Petrov M, Huang N, Guiderdoni E, Ghesquiere A (1996) Aroma in rice: genetic analysis of a quantitative trait. Theor Appl Genet 93:1145-1151. doi:10.1007/BF00230138

Mohanty A, Kathuria H, Ferjani A, Sakamoto A, Mohanty P, Murata $\mathrm{N}$ et al (2002) Transgenics of an elite indica rice variety Pusa Basmati 1 harbouring the $\operatorname{cod} A$ gene are highly tolerant to salt stress. Theor Appl Genet 106:51-57

Nakamura T, Yokota S, Muramoto Y, Tsutsui K, Oguri Y, Fukui K et al (1997) Expression of a betaine aldehyde dehydrogenase gene in rice, a glycine betaine nonaccumulator, and possible localization of its protein in peroxisomes. Plant J 11:1115-1120. doi:10.1046/j.1365-313X.1997.11051115.x

Narayan VS, Nair PM (1990) Metabolism, enzymology and possible roles of 4-aminobutyrate in higher plants. Phytochemistry 29:367-375. doi:10.1016/0031-9422(90)85081-P

Niu XL, Zheng WJ, Lu BR, Ren GJ, Huang WZ, Wang SH et al (2007) An unusual post-transcriptional processing in two Betaine aldehyde dehydrogenase loci of cereal crops directed by short, direct repeats in response to stress conditions. Plant Physiol 143:1929-1942. doi:10.1104/pp.107.095752

Oishi H, Ebina M (2005) Isolation of cDNA and enzymatic properties of betaine aldehyde dehydrogenase from Zoysia tenuifolia. J Plant Physiol 162:1077-1086. doi:10.1016/j.jplph.2005.01.020

Palanivelu R, Brass L, Edlund AF, Preuss D (2003) Pollen tube growth and Guidance is regulated by $P O P 2$, an Arabidopsis gene that controls GABA levels. Cell 114:47-59. doi:10.1016/S00928674(03)00479-3

Rajabi F, Saidi MR (2005) A cheap, simple, and versatile method for acetylation of alcohols and phenols and selective deprotection of aromatic acetates under solvent-free condition. Synth Commun 35:483-491. doi:10.1081/SCC-200048988

Rathinasabapathi B, Gage DA, Mackill DJ, Hanson AD (1993) Cultivated and wild rices do not accumulate glycine betaine due to deficiencies in two biosynthetic steps. Crop Sci 33:534-538

Reumann S (2004) Specification of the peroxisome targeting signals type 1 and type 2 of plant peroxisomes by bioinformatics analyses. Plant Physiol 135:783-800. doi:10.1104/pp.103.035584

Romanczyk LJ, Mcclelland CA, Post LS, Aitken WM (1995) Formation of 2-Acetyl-1-Pyrroline by several Bacillus cereus strains isolated from cocoa fermentation boxes. J Agric Food Chem 43:469-475. doi:10.1021/jf00050a040

Rungsardthong V, Noomhoom A (2005) Production of 2-acetyl-1pyrroline by microbial cultures. Flavour Fragrance J 20:710 714. doi:10.1002/ffj. 1645

Russell BL, Rathinasabapathi B, Hanson AD (1998) Osmotic stress induces expression of choline monooxygenase in sugar beet and amaranth. Plant Physiol 116:859-865. doi:10.1104/pp.116.2.859

Schieberle P (1995) Quantitation of important roast-smelling odorants in popcorn by stable-isotope dilution assays and model studies on flavor formation during popping. J Agric Food Chem 43:2442-2448. doi:10.1021/jf00057a024

Sebela M, Brauner F, Radova A, Jacobsen S, Havlis J, Galuszka P et al (2000) Characterisation of a homogeneous plant aminoaldehyde dehydrogenase. Biochim Biophys Acta Protein Struct Mol Enzymol 1480:329-341

Sebela M, Luhova L, Brauner F, Galuszka P, Radova A, Pec P (2001) Light microscopic localisation of aminoaldehyde dehydrogenase activity in plant tissues using nitroblue tetrazolium-based staining method. Plant Physiol Biochem 39:831-839. doi: 10.1016/S0981-9428(01)01304-3

Shelp BJ, Bown AW, Faure D (2006) Extracellular $\gamma$-aminobutyrate mediates communication between plants and other organisms. Plant Physiol 142:1350-1352. doi:10.1104/pp.106.088955

Shi W, Yang Y, Chen S, Xu M (2008) Discovery of a new fragrance allele and the development of functional markers for the breeding of fragrant rice varieties. Mol Breed (Published Online)

Shirasawa K, Takabe T, Takabe T, Kishitani S (2006) Accumulation of glycine betaine in rice plants that overexpress choline monooxygenase from spinach and evaluation of their tolerance to abiotic stress. Ann Bot (Lond) 98:565-571. doi:10.1093/ aob/mcl126

Snedden WA, Arazi T, Fromm H, Shelp BJ (1995) Calciumcalmodulin activation of soybean glutamate decarboxylase. Plant Physiol 108:543-549

Snowdon EM, Bowyer MC, Grbin PR, Bowyer PK (2006) Mousy offflavor: a review. J Agric Food Chem 54:6465-6474. doi: $10.1021 /$ jf0528613

Stone BC (1978) Studies in Malesian Pandanaceae XVII on the taxonomy of 'Pandan Wangi' a Pandanus cultivar with scented leaves. Econ Bot 32:285-293

Struve C, Christophersen C (2003) Structural equilibrium and ringchain tautomerism of aqueous solutions of 4-aminobutyraldehyde. Heterocycles 60:1907-1914

Thimmaraju R, Bhagyalakshmi N, Narayan MS, Venkatachalam L, Ravishankar GA (2005) In vitro culture of Pandanus amaryllifolius and enhancement of 2-acetyl-1-pyrroline, the major flavouring compound of aromatic rice, by precursor feeding of L-proline. J Sci Food Agric 85:2527-2534. doi:10.1002/jsfa.2286

Trossat C, Rathinasabapathi B, Hanson AD (1997) Transgenically expressed betaine aldehyde dehydrogenase efficiently catalyzes oxidation of dimethylsulfoniopropionaldehyde and omega-aminoaldehydes. Plant Physiol 113:1457-1461

Valenzuela-Soto EM, Velasco-Garcia R, Mujica-Jimenez C, GaviriaGonzalez L, Munoz-Clares RA (2003) Monovalent cations requirements for the stability of betaine aldehyde dehydrogenase from Pseudomonas aeruginosa, porcine kidney and amaranth leaves. Chem Biol Interact 143:139-148. doi:10.1016/S00092797(02)00198-9

Vanavichit A, Yoshihashi T, Wanchana S, Areekit S, Saengsraku D, Kamolsukyunyong W et al (2006) Positional cloning of Os2AP, the aromatic gene controlling the biosynthetic switch of 2-acetyl-1pyrroline and gamma aminobutyric acid (GABA) in rice (abstract). In 5th International rice genetics symposium. Manila, Philippines

Vanderbilt AS, Gaby NS, Rodwell VW (1975) Intermediates and enzymes between alpha-ketoarginine and gamma-guanidinobutyrate in the L-arginine catabolic pathway of Pseudomonas putida. J Biol Chem 250:5322-5329

Widjaja R, Craske JD, Wootton M (1996) Comparative studies on volatile components of non-fragrant and fragrant rices. J Sci Food Agric 70:151-161. doi :10.1002/(SICI)1097-0010(199602) 70:2<151::AID-JSFA478>3.0.CO;2-U

Wongpornchai S, Sriseadka T, Choonvisase S (2003) Identification and quantitation of the rice aroma compound, 2-acetyl-1pyrroline, in bread flowers (Vallaris glabra Ktze). J Agric Food Chem 51:457-462. doi:10.1021/jf025856x

Wood AJ, Saneoka H, Rhodes D, Joly RJ, Goldsbrough PB (1996) Betaine aldehyde dehydrogenase in sorghum. Plant Physiol 110:1301-1308. doi:10.1104/pp.110.4.1301 
Yorifuji T, Koike K, Sakurai T, Yokoyama K (1986) 4-Aminobutyraldehyde and 4-guanidinobutyraldehyde dehydrogenases for arginine degradation in Pseudomonas putida. Agric Biol Chem 50:2009-2016

Yoshihashi T (2002) Quantitative analysis on 2-acetyl-1-pyrroline of an aromatic rice by stable isotope dilution method and model studies on its formation during cooking. J Food Sci 67:619-622. doi:10.1111/j.1365-2621.2002.tb10648.x

Yoshihashi T, Huong NTT, Inatomi H (2002) Precursors of 2-acetyl-1pyrroline, a potent flavor compound of an aromatic rice variety. J Agric Food Chem 50:2001-2004. doi:10.1021/jf011268s
Yoshihashi T, Huong NTT, Surojanametakul V, Tungtrakul P, Varanyanond W (2005) Effect of storage conditions on 2-acetyl-1-pyrroline content in aromatic rice variety, Khao Dawk Mali 105. J Food Sci 70:S34-S37

Zehentbauer G, Grosch W (1998) Crust aroma of baguettes I. Key odorants of baguettes prepared in two different ways. J Cereal Sci 28:81-92. doi:10.1006/jcrs.1998.0184

Zehentbauer G, Reineccius GA (2002) Determination of key aroma components of Cheddar cheese using dynamic headspace dilution assay. Flavour Fragrance J 17:300-305. doi:10.1002/ ffj. 1102 